\title{
PENINGKATAN KEMAMPUAN SISWA MENULIS TEKS NEGOSIASI DENGAN MENGGUNAKAN METODE KARYAWISATA KELAS X IPA 1 MAN 1 BULELENG
}

\author{
Abu Farhan ${ }^{1}$, I Nengah Martha ${ }^{2}$, Idb. Putrayasa ${ }^{3}$ \\ Jurusan Pendidikan Bahasa dan Sastra Indonesia, Fakultas Bahasa dan Seni \\ Universitas Pendidikan Ganesha \\ Singaraja, Indonesia
}

e-mail: \{abufarhan661@gmail.com ${ }^{1}$, nengahmartha@yahoo.com²

\begin{abstract}
ABSTRAK
Penelitian tindakan kelas yang dilakukan di MAN 1 Buleleng ini bertujuan (1) mengidentifikasi langkah-langkah penggunaan metode karyawisata dalam meningkatkan kemampuan menulis teks negosiasi siswa kelas X IPA 1 MAN 1 Buleleng (2) mengetahui peningkatan kemampuan menulis teks negosiasi siswa dengan menggunakan metode karyawisata, dan (3) mengetahui respons siswa terhadap penggunaan metode karyawisata dalam pembelajaran menulis teksnegosiasi. Penelitian ini menggunakan rancangan PTK. Subjek dalam penelitian ini adalah buk Sriwahyuni dan siswa kelas X IPA 1 , sedangkan objek dalam penelitian ini adalah penggunaan metode karyawisata. Data dikumpulkan dengan metode observasi, tes, angket/kuisioner, serta wawancara. Data yang terkumpul dianalisis secara deskriptif kuantitatif dan kualitatif. Hasil penelitian menunjukkan (1) Terdapat beberapa langkah pembelajaran dalam penggunaan metode karyawisata untuk meningkatkan kemampuan menulis teks negosiasi siswa kelas X IPA 1 MAN 1 Buleleng. Langkah tersebut yakni (a) memberi apersepsi dan motivasi, (b) menyampaikan materi dengan jelas, (c) menetapkan dan mempelajari objek, (d) pelaksanaan karyawisata, (e) menjelaskan kriteria penilaian, (f) kegiatan menulis, (g) terakhir penutup. (2) Nilai kemampuan menulis teks negosiasi siswa mengalami peningkatan, hal ini dibuktikan dengan nilai rata-rata dari prasiklus $(65,00)$, siklus I $(75,91)$, dan siklus II $(83,81)(3)$ Siswa memberikan respons positif terhadap pelaksanaan pembelajaran teks negosiiasi dengan menggunakan metode karyawisata. Penggunaan metode karyawisata dalam pembelajaran menulis teks negosiasi mampu meningkatkan prestasi siswa dalam menulis dan penggunaan metode ini juga mendapat respons yang positif dari siswa.
\end{abstract}

Kata kunci: metode karyawisata, teks negosiasi, siswa MAN.

\begin{abstract}
This classroom action research was done in MAN 1 Buleleng aimed to: (1) identifying the steps of using field trip method to improve writing negotiation text for 10th grade science students in MAN Buleleng, (2) investigating the competency on writing negotiation text by using field trip method, and (3) investigating the students' response toward the use of field trip method in learning writing negotiation text.
\end{abstract}


This research uses PTK design. Subjects in this study were the capital Sriwahyuni and 10th grade science students, while the object in this study is the use of the method of field trip. The data was collected by using observation, test, questionnaire and interview and then the data was analyzed by using descriptive quantitative and qualitative. The results showed (1) There are several learning steps in the use of field trip method to improve the ability to write the text of negotiation of students of class X IPA 1 MAN 1 Buleleng. That step is (a) give the apperception and motivation, (b) convey material clearly, (c) establish and study objects, (d) execution of field trips, (e) explains the assessment criteria, (f) the writing activity, (g) the final closing. (2) The value of students' writing negotiation text skills has increased, this is evidenced by the average value of prasiklus $(65,00)$, cycle I $(75,91)$, and cycle II $(83,81)$. (3) Students give positive responses to the implementation of negotiated text lessons using field trip method. The use of field trip method in learning to write negotiation text able to improve student achievement in writing and use of this method also get positive response from student.

Keywords: field trip study method, negotiation text, student MAN

\section{PENDAHULUAN}

Negosiasi secara umum adalah suatu bentuk interaksi sosial antara dua pihak atau lebih yang berusaha untuk saling menyelesaikan tujuan yang berbeda dan bertentangan demi mencari jalan keluar dan kesepakatan bersama. Sejalan dengan itu, Kemendikbud (2013:134) menyatakan bahwa negosiasi adalah bentuk interaksi sosial yang berfungsi untuk mencapai kesepakatan diantara pihak-pihak yang mempunyai kepentingan yang berbeda. Dalam negosiasi, pihak-pihak tersebut berusaha menyelesaikan perbedaan itu dengan berdialog. Ketika bernegosiasi, pihak yang terlibat harus mampu menyampaikan tujuannya dengan baik dan mampu memberikan tanggapan dengan baik juga. Jika tidak, hal tersebut dapat mengakibatkan masalah tidak dapat diselesaikan atau justru malah menimbulkan masalah baru. Agar mampu bernegosiasi dengan baik manusia perlu belajar.

Belajar mengenai negosiasi sangatlah penting. Setiap manusia pasti selalu berinteraksi dengan manusia lainnya, dalam interaksi sosial ini manusia sering menemukan masalah yang perlu diselesaikan, dan salah satu cara untuk menyelesaikan masalah tersebut ialah melalui negosiasi. Melalui belajar negosiasi diharapkan manusia mampu menyelesaikan masalahnya dengan cara terbaik, yang didukung dengan keterampilan berbicara menggunakan bahasa yang baik dan benar.

Pada dunia pendidikan, negosiasi dipelajari di sekolah yang menerapkan Kurikulum 2013. Pembelajaran mengenai negosiasi dipelajari pada jenjang Sekolah Menengah Atas (SMA) kelas $X$ tepatnya pada bidang studi Bahasa Indonesia. Memproduksi atau menulis teks negosiasi sendiri merupakan salah satu materi yang terdapat dalam Kompetensi Dasar (KD no. 4.11) kelas $X$ tingkat SMA dalam Kurikulum 2013 (Kurtilas) yang berbunyi: Mengkonstruksikan teks negosiasi dengan memerhatikan isi, struktur (orientasi, pengajuan, penawaran, persetujuan, penutup) dan kebahasaan.

Kurikulum 2013 menekankan pembelajaran bahasa berbasis teks. Pola pembelajaran bahasa berbasis teks akan menuntun peserta didik untuk mengenal berbagai macam jenis teks, yang salah satunya adalah teks negosiasi. Melalui pembelajaran berbasis teks ini peserta didik dituntun untuk mampu menggunakan bahasa ke dalam teks negosiasi. Penggunaan bahasa harus disesuaikan dengan konteks teksnya dan fungsi bahasa itu sendiri, apakah untuk menggugah perasaan (fungsi bahasa secara estetis) atau untuk memberikan pemahaman (fungsi bahasa secara logis). Pada konteks pembelajaran teks negosiasi, peserta didik 
tentu akan menyesuaikan penggunaan bahasa untuk memberikan pemahaman.

Mengingat pentingnya teks negosiasi dikuasai oleh siswa, guru sangat berperan dalam proses pembelajaran. Guru dituntut mampu menerapkan model pembelajaran yang tepat. Namun, pada kenyataannya guru seringkali hanya menyampaikan teori definisi teks negosiasi, struktur teks negosiasi, dan unsur-unsur kebahasaan yang ada dalam teks laporan hasil observasi. Sehingga membuat siswa susah dalam mencapai indikator pembelajaran

Hal ini ditemukan penulis setelah melakukan observasi awal di sekolah MAN 1 Buleleng. MAN 1 Buleleng dipilih sebagai tempat penelitian dengan alasan sebagai berikut. Pertama, MAN 1 Buleleng merupakan satu di antara sekolah yang sudah menggunakan kurikulum 2013. Kedua, berdasarkan pengamatan penulis di lapangan, penulis juga melihat bahwa guru di MAN 1 Buleleng merasa kesulitan untuk menggunakan kurikulum 2013. Ketiga, hasil belajar siswa di MAN Buleleng masih rendah dibandingkan SMA Negeri yang lain dikarenakan berbagai macam faktor.

Berdasarkan hasil wawancara dengan guru bahasa Indonesia yang mengajar di kelas X IPA 1, dapat diketahui seluk-beluk kemampuan siswa dalam menulis. Masalah yang terjadi di dalam kelas dilatarbelakangi oleh beberapa alasan sebagai berikut. Pertama, siswa kelas X IPA 1 kurang dalam keterampilan menulis karena siswa ketika ditugaskan untuk menulis kebanyakan tidak bisa mengerjakan tugas dengan baik. Kedua, guru hanya menggunakan metode ceramah yang berpatokan pada buku Lembar Kerja Siswa (LKS) tanpa adanya buku teks sehingga dalam mengikuti pembelajaran siswa cenderung pasif. Ketiga, siswa susah mengemukakan dan mengembangkan ide-ide secara jelas. Keempat, dari segi kata dan kalimat, siswa sering melakukan kesalahan dalam bentuk maupun pilihan kata dan kurang menguasai tata kalimat. Padahal, dalam menulis teks laporan hasil observasi, semua aspek tersebut harus dikuasai dengan baik. Kelima, siswa merasa bosan karena kurangnya kesempatan siswa untuk aktif dalam pembelajaran.

Akibatnya, skor yang diperoleh siswa dalam materi ini sebagian besar di bawah KKM. Dari 33 siswa, hanya 12 siswa yang mampu memeroleh nilai sesuai KKM, jika dipersentasikan sebesar $35 \%$ saja. Sedangkan sisanya yakni 21 siswa kemampuannya masih di bawah KKM, jika dipersentasikan sebanyak $65 \%$ yang mendapat nilai tidak tuntas.

Kesulitan yang dialami dalam menulis teks negosiasi tersebut disebabkan oleh tidak tepatnya model yang digunakan guru dalam mengajar. Selama melakukan aktivitas mengajar di kelas, guru belum menerapkan model pembelajaran yang inovatif. Dalam menyampaikan materi, guru hanya menggunakan metode ceramah yang sifatnya teoritis. Setelah menjelaskan materi, guru melanjutkan pembelajaran dengan pemberian tugas tanpa diawali contoh. Dengan proses pembelajaran seperti itu, tentu siswa cenderung bosan dan kurang memperhatikan penjelasan materi dari guru. Strategi yang seperti itu juga mengakibatkan aktivitas belajarmengajar kurang memadai karena tidak adanya variasi yang dilakukan oleh guru saat mengajar di kelas. Hal ini diperkuat oleh Surya (2003:5) yang menyatakan bahwa perhatian, minat, dan motivasi sangat penting dalam upaya melakukan kegiatan belajar-mengajar. Untuk mencapai tujuan tertentu dalam pembelajaran perlu dilakukan sesuatu yang dapat membantu proses pembelajaran agar berjalan dengan lancar.

Berangkat dari permasalahan tersebut, diperlukan suatu metode baru yang menarik untuk menunjang proses pembelajaran sehingga proses pembelajaran menjadi lebih aktif, efektif, 
dan menyenangkan. Dalam proses belajar mengajar terdapat beberapa metode yang dapat merangsang kreativitas dan minat siswa terhadap pelajaran, salah satunya dengan pembelajaran di luar sekolah melalui metode karyawisata. Dengan adanya metode ini akan memudahkan siswa dalam menulis. Hal itu dikarenakan, siswa akan mengalami langsung sebuah proses bernegosiasi dengan berkaryawista ke suatu tempat yang telah ditentukan yakni pasar. Pasar sendiri merupakan salah satu tempat yang di dalamnya banyak dijumpai proses bernegosiasi. Oleh karena itu, metode ini sangat cocok dengan pembelajaran teks negosiasi

Nurmaliah (2014:24) menyatakan bahwa Karyawisata atau studi wisata sebagai metode pembelajaran adalah siswa di bawah bimbingan guru mengunjungi tempat-tempat tertentu dengan maksud untuk mempelajari objek belajar yang ada di tempat itu. Field trip atau karyawisata tidak hanya pergi bergembira saja, tetapi siswa juga dapat belajar dan perjalanan karyawisata dengan belajar akan membantu meningkatkan kognitif dan keterampilan siswa. Dengan melaksanakan karyawisata diharapkan siswa dapat memperoleh pengalaman langsung dari objek yang dilihatnya

Sejalan dengan itu, Ismawati (2012: 82) juga mengatakan bahwa metode karyawisata adalah suatu cara menyajikan bahan pelajaran dengan membawa siswa langsung kepada objek yang akan dipelajari yang terdapat di luar kelas. Dengan demikian, siswa akan terjun langsung ke lapangan untuk mendapatkan data yang dibutuhkan dalam proses pembelajaran, sehingga siswa akan memperoleh pengalaman baru sekaligus meningkatkan motivasi dan kreatifitas dalam membuat teks negosiasi.

Adapun beberapa penelitian sejenis yang relevan dengan penelitian yang peneliti kaji, di antaranya yaitu penelitian dalam bentuk skripsi yang dilakukan oleh Putu Novita Susiyanti Dewi (2015). Penelitian tersebut berjudul "Implementasi Pembelajaran Menulis Teks Negosiasi Berdasarkan Kurikulum 2013 di Kelas XB Akuntansi SMK Negeri 1 Singaraja". Penelitian tersebut dirancang dalam bentuk penelitian deskriptif kuantitatif. Persamaan antara penelitian yang dilakukan oloeh Novita dan penelitian yang peneliti lakukan adalah sama-sama mengkaji tentang pembelajaran menulis teks negosiasi. Sedangkan perbedaannya terlihat pada jenis dan tempat penelitian. Jenis penelitian yang yang dilakukan oleh Dewi adalah penelitian deskriptif kuantitatif, sedangkan jenis penelitian yang peneliti lakukan adalah penelitian PTK. Selain itu, tempat penelitian yang dilakukan oleh Dewi adalah di SMK Negeri 1 Singaraja, sementara peneliti melakukan penelitian di MAN Patas.

Penelitian dalam bentuk skripsi yang sejenis juga pernah dilakukan oleh Ade Yuanita Taufani (2014). Penelitian tersebut berjudul "Penerapan Metode Pembelajaran Bermain Peran (Role Playing) untuk Meningkatkan Hasil Belajar Menulis Teks Negosiasi pada Siswa Kelas X SMA Negeri 4 Jember". Penelitian tersebut dirancang dalam bentuk Penelitian Tindakan Kelas (PTK). Persamaan penelitian yang dilakukan oleh Taufani, dan penelitian yang peneliti lakukan terletak dari objek penelitiannya yakni keterampilan menulis teks negosiasi. Sedangkan perbedaannya terlihat pada metode yang ditawarkan dan tempat penelitannya. Metode yang ditawarkan dalam penelitaian Taufani. adalah metode pembelajaran bermain peran (role playing), sedangkan metode yang ditawarkan peneliti adalah metode karyawisata. Selain itu, tempat penelitian Taufani. dilakukan di SMA Negeri 4 Jember, sedangkan penelitian yang peneliti lakukan di MAN 1 Buleleng.

Berdasarkan hal itu, sudah jelas terlihat perbedaan antara penelitian ini dan 
penelitian yang lain terletak pada fokus permasalahan yang akan dikaji. Penelitian PTK, "Peningkatan Kemampuan Siswa Menulis Teks Negosiasi dengan Menggunakan Metode Karyawisata Kelas X IPA 1 MAN 1 Buleleng", ini menarik dan sangat penting untuk dilakukan. Sehingga nantinya akan diketahui langkah-langkah atau penerapan serta hasil dan respons siswa terhadap metode yang ditawarkan peneliti.

Dilihat dari masalah di atas, penelitian ini membahas masalah tentang, Bagaimanakah penerapan metode karya wisata dalam pembelajaran menulis teks negosiasi di kelas X IPA 1 MAN 1 Buleleng ?, (2) Bagaimana hasil kemampuan siswa setelah menggunakan metode karya wisata dalam pembelajaran menulis teks negosiasi di kelas X IPA 1 MAN 1 Buleleng ?, dan (3) Bagaimana respons siswa setelah menggunakan metode karya wisata dalam pembelajaran menulis teks negosiasi di kelas X IPA 1 MAN 1 Buleleng ?

Sejalan dengan rumusan masalah yang telah diuraikan di atas, tujuan penelitian ini adalah (1) untuk medeskripsikan langkah-langkah pembelajaran menulis teks negosiasi di kelas X IPA 1 MAN 1 Buleleng, (2) untuk medeskripsikan hasil kemampuan siswa setelah menggunakan metode karya wisata dalam pembelajaran menulis teks negosiasi di kelas X IPA 1 MAN 1 Buleleng, dan (3) untuk medeskripsikan respons siswa setelah menggunakan metode karya wisata dalam pembelajaran menulis teks negosiasi di kelas X IPA 1 MAN 1 Buleleng

Hasil dari penelitian ini diharapkan memberikan manfaat bagi siswa, guru, sekolah, dan peneliti lainnya.

\section{METODE PENELITIAN}

Penelitian ini menggunakan rancangan penelitian tindakan kelas. Penelitian tindakan kelas ini dilaksanakan di MAN 1 Buleleng.
Subjek dalam penelitian ini adalah guru mata pelajaran bahasa Indonesia di kelas X IPA 1 yang bernama Sri Wahyuni, S.Pd dan siswa kelas X IPA 1 MAN 1 Buleleng. Siswa kelas $X$ dipilih sebagai subjek penelitian karena kemampuan menulis teks negosiasi masih kurang dan hal tersebut dibuktikan melalui nilai yang diperoleh siswa masih di bawah KKM, yaitu 76.

Objek penelitian merupakan hal yang dikaji dalam penelitian tersebut. Objek dalam penelitian ini adalah penggunaan metode karyawisata dalam meningkatkan kemampuan menulis teks negosiasi siswa kelas X IPA 1 dan respons siswa terhadap pembelajaran.

Dalam pengumpulan data penelitian, peneliti menggunakan beberapa metode pengumpulan data. Pertama, untuk mengetahui langkah-langkah penggunaan metode karyawisata dalam pembelajaran, peneliti menggunakan metode observasi sebagai penilaian proses. Kedua, untuk mengetahui peningkatan kemampuan menulis siswa, peneliti menggunakan metode tes berupa unjuk kerja berbentuk tulis. Ketiga,untuk mengetahui respons siswa, peneliti menggunakan metode angket/ kuesioner dan wawancara.

Data dalam penelitian ini, dianalisi dengan teknik deskriptif kuantitatif dan deskriptif kualitatif. Berdasarkan ketiga jenis data yang diperoleh, langkah-langkah penggunaan metode karyawisata dalam meningkatkan kemampuan menulis teks negosiasi siswa dianalisis dengan teknik analisis data deskriptif kualitatif, hasil kemampuan menulis teks negosiasi siswa dengan menggunaan metode karyawisata dianalisis dengan teknik deskriptif kuantitatif, dan respons siswa dianalisis dengan deskriptif kuantitatif dan kualitatif.

Analisis data hasil belajar dilakukan untuk kedua siklus, yaitu siklus I dan siklus II dengan tujuan mengukur hasil kemampuan menulis teks negosiasi dengan 
menggunakan metode karyawisata. Hasil tes pada siklus I dianalisis, dilanjutkan dengan mencari kesulitan-kesulitan yang dialami siswa selama proses pembelajaran. Pada siklus II diharapkan siswa mendapatkan hasil yang baik.

\begin{tabular}{|c|c|c|c|c|}
\hline No. & Kat. & R.N. & F. & $\mathbf{\%}$ \\
\hline 1. & Sangat Baik & $85-100$ & 4 & $12,5 \%$ \\
\hline 2. & Baik & $70-84$ & 23 & $71,9 \%$ \\
\hline 3. & Cukup & $60-69$ & 5 & $15,6 \%$ \\
\hline 4. & Kurang & $50-69$ & 0 & $0 \%$ \\
\hline 5. & Gagal & $0-44$ & 0 & $0 \%$ \\
\hline & Jumlah & & $\mathbf{3 2}$ & $\mathbf{1 0 0 \%}$ \\
\hline
\end{tabular}

Kriteria keberhasilan penelitian adalah kemampuan membaca siswa dikatakan berhasil apabila 75\% dari keseluruhan siswa memeroleh nilai 76 ke atas atau melebihi KKM, sedangkan untuk respons, penggunaan metode karyawisata dapat dikatakan diterima dengan baik oleh siswa apabila $75 \%$ siswa memberikan respons positif.

\section{HASIL PENELITIAN DAN PEMBAHASAN}

\section{Hasil Penelitian}

Setelah dilakukan penelitian mengenai penggunaan metode karyawisata dalam meningkatkan kemampuan menulis teks negosiasi siswa kelas $X$ IPA 1 MAN 1 Buleleng, dapat diketahui hasil penelitian sebagai berikut.

Pelaksanaan tindakan pada siklus I dilakukan dalam dua kali pertemuan. Pertemuan pertama siklus I dilaksanakan pada sabtu 10 Maret 2018, pada jam pelajaran 4-5. Dengan alokasi waktu $2 \times 45$ manit, yaitu mulai pukul 10.15 WITA sampai pukul 12.45 WITA. Pertemuan kedua dilaksanakan pada pada selasa, 13 Maret 2018, pada jam pelajaran 1-2. Dengan alokasi waktu $2 \times 45$ menit, yaitu mulai pukul 07.00 WITA sampai pukul 08.30 WITA. Langkah-langkah pelaksanaan tindakan akan dipaparkan sebagai berikut.
Berdasarkan hasil observasi yang dilakukan, dapat dikatakan bahwa langkahlangkah pelaksanaan pembelajaran yang dilakukan sudah tergolong baik/bagus. Hal ini dapat dilihat dari penilaian yang diberikan peneliti atau observer saat mengamati guru mengajar.

Hasil tes kemampuan menulis teks negosiasi siswa pada siklus I, dapat dilihat dalam tabel sebagai berikut.

\section{Tabel 1.1 Hasil Tes Kemampuan Menulis Teks Negosiasi Siswa Siklus I}

Keterangan;

Kat :Kategori

R.N. :Rentangan Nilai

F. :Frekuensi

Berdasarkan tabel hasil keseluruhan pada siklus I, diperoleh rata-rata 75,91 yang secara klasikal berkategori baik.

Berdasarkan tabel di atas dapat diketahui bahwa kemampuan siswa kelas $X \quad I P A \quad 1$ MAN 1 Buleleng setelah mendapatkan tindakan dari 32 orang siswa, terdapat 4 siswa atau 12,5\% memperoleh kategori sangat baik, 23 siswa atau $71,9 \%$ memperoleh kategori baik, 5 siswa atau $15 \%$ memperoleh kategori cukup dan tidak ada siswa yang memeroleh kategori kurangdan gagal.

Dengan nilai rata-rata sebesar 75,9 maka terjadi peningkatan nilai dari pratindakan sebesar 10,91\%. Jika dilihat dari nilai yang ditargetkan pada siklus I yaitu 76, maka terdapat 10 siswa yang masih berada di bawah nilai rata-rata (nilai KKM). Oleh karena itu, dilanjutkan pada siklus II dengan harapan siswa mampu mencapai nilai 76 .

Berdasarkan hasil respons siswa pada siklus I, dapat dirinci dari 32 siswa yang telah mengisi angket, terdapat 14 siswa $(43,75 \%)$ yang memberikan respons sangat positif. Sisanya, terdapat 13 siswa $(40,63 \%)$ memberikan respons positif dan 5 siswa $(15,63 \%)$ memberikan respons cukup positif. Dari 32 siswa di kelas X IPA 1 MAN 
1 Buleleng, tidak ada siswa yang memberikan respons yang kurang positif ataupun sangat kurang positif. Secara keselutuhan, rata rata respons yang diperoleh dalam pelaksanaan siklus I, yaitu 42,59 (dalam kategori positif).

Hambatan-hambatan yang ditemukan pada siklus I adalah berikut ini (1) Siswa kurang fokus atau berkonsentrasi saat pembelajaran di dalam kelas maupun di luar kelas yakni pasar, (2) Pedagang yang ada di pasar Patas tidak terlalu banyak dan ada beberapa pedagang yang tidak terlalu merespons siswa saat melakukan transaksi, sehingga siswa susah untuk menego barang yang hendak dibeli. (3) Pada saat kegiatan menulis, guru kurang melakukan pengamatan atau pendekatan kepada siswa. Selain itu, ketika siswa menemukan kendala, siswa cenderung tidak mau bertanya dengan teman maupun guru. (4) Siswa cenderung belum bisa memberikan argumen ketika bernegosiasi maupun saat menulis. Selain itu, terdapat pula kekurangan dalam pengembangan isi, keruntutan pemaparan, ejaan, diksi dan kalimat. (5) Guru kurang terperinci ketika menjelaskan langkah-langkah menulis teks negosiasi. Guru hanya menjelaskan materi secara umum. Oleh sebab itu, siswa mengalami kesulitan dalam memulai mengembangkan tulisannya. (6) Sebelum kegiatan menulis teks negosiasi berlangsung, guru tidak menjelaskan aspekaspek yang akan dinilai. Oleh sebab itu, siswa tidak mengetahui aspek-aspek yang dinilai pada teks negosiasi siswa.

Hasil tes keterampilan menulis teks negosiasi siswa kelas $X$ IPA 1 MAN 1 Buleleng, secara keseluruhan tergolong baik dengan rata-rata 75,9. Siswa yang memperoleh nilai sesuai KMM sebesar $68,7 \%$. Namun, pembelajaran menulis teks negosiasi menggunakan metode karyawisata belum mencapai kriteria keberhasilan, yakni $75 \%$ siswa mendapat skor 76 ke atas atau sesuai KKM, sehingga metode ini dianalisis lagi dan tindakan dilanjutkan ke siklus II dengan perencanaan yang lebih matang agar hambatanhambatan pada siklus I dapat diperbaiki pada siklus II.

Berikut hasil keseluruhan pada siklus II. Tindakan Siklus II dalam penelitian ini dilakukan dalam dua kali pertemuan. Pertemuan pertama siklus II dilaksanakan pada Selasa, 20 Maret 2018 pada jam pelajaran pertama dan kedua (1-2). Pertemuan pertama ini dimulai pada pukul 07.00 WITA dan berakhir pada pukul 08.30 WITA. Pertemuan kedua siklus II dilaksanakan pada Sabtu, 24 Maret 2018 pada jam pelajaran keempat dan kelima (45). Pertemuan kedua ini dimulai pada pukul 09.15 WITA dan berakhir pada pukul 11.00 WITA.

Hasil observasi pada pelaksanaan pembelajaran pada siklus II, bahwa langkah-langkah kegiatan pembelajaran yang dilakukan oleh guru tergolong sangat baik. Hal itu dapat diamati dari penilaian yang diberikan oleh observer/peneliti saat mengamati guru.Guru sudah melaksanakan kegiatan pembelajaran ini sesuai prosedur yang sudah direncanakan pada kegiatan refleksi siklus I. Pelaksanaan pembelajaran pada siklus II sudah dapat dikatakan lebih baik dari pelaksanaan pembelajaran siklus I

Berdasarkan hasil tes pada siklus II kemampuan menulis teks negosiasi siswa dengan menggunakan metode karyawisata kelas X IPA 1 MAN 1 Bulelng dapat dilihat dalam tabel berikut ini.

Tabel 1.2 Hasil Tes Kemampuan Menulis Teks Negosiasi Siswa Siklus II

\begin{tabular}{|c|c|c|c|c|}
\hline No. & Kat. & R.N. & F. & \% \\
\hline 1. & Sangat Baik & $85-100$ & 14 & $43,8 \%$ \\
\hline 2. & Baik & $70-84$ & 18 & $56,2 \%$ \\
\hline 3. & Cukup & $60-69$ & 0 & $0 \%$ \\
\hline 4. & Kurang & $50-69$ & 0 & $0 \%$ \\
\hline 5. & Gagal & $0-44$ & 0 & $0 \%$ \\
\hline & Jumlah & & $\mathbf{3 2}$ & $\mathbf{1 0 0 \%}$ \\
\hline
\end{tabular}

Keterangan; 
Kat :Kategori

R.N. :Rentangan Nilai

F. :Frekuensi

Berdasarkan tabel hasil keseluruhan pada siklus II, diperoleh rata-rata 83,81 yang secara klasikal berkategori baik.

Dari tabel 1.2 di atas, dapat dideskripsikan tidak ada siswa yang masuk dalam kategori cukup, kurang, dan gagal. Siswa yang masuk dalam kategori baik sebanyak 18 orang atau $56,2 \%$. Siswa yang masuk dalam kategori sangat baik sebanyak 14 orang atau 43,8\%. Secara klasikal, ketuntasan siswa mencapai 84,4\%. Hal ini berarti, siswa kelas X IPA 1 MAN 1 Buleleng dapat dikatakan memenuhi syarat ketuntasan yang ditetapkan, yaitu $75 \%$.

Pada siklus I, skor rata-rata siswa adalah 75,91 sementara pada siklus II adalah 83,81 . Hal ini berarti skor rata-rata kemampuan menulis teks negosiasi siswa dengan menggunakan metode karyawisata mengalami peningkatan sebesar 7,9.

Berdasarkan hasil respons siswa pada siklus II, dapat dirinci dari 32 siswa yang telah mengisi angket, terdapat 16 siswa $(50 \%)$ yang memberikan respons sangat positif. Sisanya, terdapat 14 siswa $(43,75 \%)$ memberikan respons positif dan 2 siswa (6,25\%) memberikan respons cukup positif. Dari 32 siswa di kelas X IPA 1 MAN 1 Buleleng, tidak ada siswa yang memberikan respons yang kurang positif ataupun sangat kurang positif. Secara keselutuhan, rata rata respons yang diperoleh dalam pelaksanaan siklus II, yaitu 43,72 (dalam kategori positif). Mengalami peningkatan sebesar 1,13 dari siklus sebelumnya.

Kemudian, yang dilakukan oleh peneliti bersama guru pada akhir siklus II adalah menunjukkan bahwa pelaksanaan pembelajaran menulis teks negosiasi dengan menggunakan metode karyawisata secara umum telah berjalan sesuai dengan rencana. Hasil catatan lapangan dan tes kemampuan membaca siswa menunjukkan bahwa indikator keberhasilan penelitian ini telah tercapai sehingga tindakan dihentikan.

\section{Pembahasan}

Ada beberapa temuan penting yang dibahas pada bagian ini. (1) terdapat beberapa langkah penerapan metode karyawisata untuk meningkatkan kemampuan dan tercapainnya ketuntasan hasil belajar menulis teks negosiasi, (2) tercapainnya peningkatan dan ketuntasan hasil belajar menulis teks negosiasi siswa $X$ IPA 1 MAN 1 Buleleng menggunakan metode karyawisata, (3) siswa memberikan respons positif terhadap penerapan metode karyawisata. Temuan-temuan tersebut diuraikan sebagai berikut.

Temuan pertama, Langkah-langkah pembelajaran yang diterapkan pada pembelajaran menulis teks negosiasi memiliki peran yang cukup besar terhadap peningkatan kualitas hasil belajar siswa. Dalam proses pembelajaran menulis teks negosiasi menggunakan metode karyawisata, ada beberapa langkah yang harus dilalui agar keterampilan menulis teks negosiasi siswa bisa meningkat. Dalam pengimplementasiannya, tempat yang dijadikan objek yang sesuai dengan kondisi lingkungan maupun kesesuaian dengan materi yang dipelajari, yaitu pasar yang berada di desa Gerokgak.

Sebelum siswa diarahkan untuk ke pasar Gerokgak, siswa terlebih dahulu diperkenalkan dengan hubungan antara materi yang dipelajari, metode, dan objek. $\mathrm{Hal}$ ini bertujuan untuk memperjelas pemahaman siswa antara ketiga aspek tersebut. Pada kegiatan awal guru memberikan apersepsi dan motivasi terhadap siswa karena sangat berpengaruh terhadap keberhasilan siswa dalam mencapai tujuan pembelajaran.

Tulisan ini dibuat berdasarkan dari pengalaman siswa itu sendiri selama 
mengikuti kegiatan karyawisata. Dalam hal ini siswa akan dibantu oleh media berupa rekaman atau video yang dibuat saat berkaryawisata. Selain itu, guru perlu menjelaskan aspek-aspek yang dinilai dalam tulisan siswa. Hal ini perlu diketahui karena menyangkut penilaian terhadap tulisan siswa. Penilain yang digunakan guru adalah penilaian dengan pendekatan analisis. Hal tersebut senada dengan teori yang dikemukakan oleh Burhan (dalam Hagashita 2016:104) Penilaian dengan pendekatan analisis merinci karangan ke dalam aspek-aspek seperti content (isi, gagasan yang dikemukakan), form (organisasi isi), grammar (tata bahasa dan pola kalimat), style (gaya pilihan struktur dan kosakata), dan mechanics (ejaan).

Temuan kedua, dengan menerapkan langkah-langkah pembelajaran tersebut kemampuan menulis teks negosiasi meningkat. Hal ini terlihat dari peningkatan hasil keterampilan menulis teks negosiasi siswa. Hasil belajar menulis teks negosiasi dengan menggunakan metode karyawisata siswa kelas X IPA 1 MAN 1 Buleleng yang dilakukan melalui siklus I dan siklus II mengalami peningkatan yang signifikan. Nilai rata-rata pada prasiklus mengalami peningkatan pada siklus I dan meningkat lagi pada siklus II. Nilai rata-rata prasiklus, siklus I, dan siklus II secara berurutan adalah 65,00 (cukup), 75,91 (baik), dan 83,81 (baik). Nilai rata-rata kelas pada siklus II telah mencapai kriteria ketuntasan minimal, yaitu 76 dengan nilai rata-rata kelas 83,81 . Hal tersebut dipertegas dengan pendapat Dimyati dan Mudjiono (dalam Hagshita 2016:106) Hasil belajar merupakan hasil yang dicapai dalam bentuk angka-angka atau sekor akhir setelah diberikan tes hasil belajar pada setiap akhir pembelajaran. Nilai yang diperoleh siswa menjadi acuan untuk melihat penugasan siswa dalam menerima materi pelajaran. Oleh karena itu, penilitian ini telah berhasil meningkatan keterampilan siswa dalam menulis teks negosiasi tidak perlu diulang pada siklus berikutnya.

Keberhasilan penelitian menulis teks negosiasi dengan menggunakan metode karyawisata siswa kelas X IPA 1 MAN 1 Buleleng juga dibuktikan dari jumlah siswa yang memperoleh nilai sesuai KKM. Berdasarkan hasil penelitian yang dilakukan pada siklus I, sebanyak 22 siswa memperoleh nilai sesuai KKM atau $68,7 \%$, dan siswa yang mendapat nilai di bawah KKM sebanyak 10 siswa atau $31,3 \%$. Sedangkan pada siklus II sebanyak 27 siswa memperoleh nilai sesuai KKM atau jika dipersentasikan sebesar $84,4 \%$, dan siswa yang mendapat nilai di bawah KKM sebanyak 5 siswa atau 15,6\%. Dari kedua siklus terjadi peningkatan sebesar $15,7 \%$. (sesuai KKM), sehingga tindakan bisa dihentikan.

Hal tersebut sejalan dengan penelitian yang dilakukan oleh Nelly Hagashita pada tahun 2016 dengan judul "Peningkatan Keterampilan Menulis Teks Laporan Hasil Observasi melalui Model Jurisprudensial Berbasis Wisata Lapangan pada Siswa Kelas X IPA 2 SMA Negeri 3 Singaraja". Hasil penelitian ditunjukkan dari persentase ketuntasan. Data refleksi awal menunjukkan bahwa siswa yang tuntas pada kompetensi dasar mendiskusikan masalah (yang ditemukan dari berbagai berita, artikel atau buku) sebesar $37,5 \%$. Pada siklus I, siswa yang tuntas sebesar $54,16 \%$ dan pada siklus II, siswa yang tuntas sebesar 79,16. Keberhasilan penelitian ini menunjukkan bahwa peningkatkan kemampuan menulis teks laporan hasil observasi siswa kelas $X$ IPA SMA Negeri 3 Singaraja dipengaruhi oleh model jurisprudensial berbasis wisata lapangan.

Temuan ketiga, yaitu siswa menjadi sangat senang dan aktif mengikuti pembelajaran menulis teks negosiasi dengan menggunakan metode karyawisata. Rasa senang dan aktif tersebut dapat dilihat dari rata-rata respons siswa yang positif. 
Hasil belajar adalah kemampuan yang dimiliki siswa setelah ia menerima pengalaman belajarnya (Sudjana, 2002:7). Pada siklus I skor rata-rata respons siswa adalah 42,59 (positif), kemudian skor ratarata respons siswa meningkat menjadi 43,72 (positif) pada siklus II.

Hasil penelitian ini sejalan dengan penelitian oleh Ade Yuanita Taufani (2014). Penelitian tersebut berjudul "Penerapan Metode Pembelajaran Bermain Peran (Role Playing) untuk Meningkatkan Hasil Belajar Menulis Teks Negosiasi pada Siswa Kelas $X$ SMA Negeri 4 Jember". Siswa memberikan tanggapan sangat positif terhadap proses pembelajarannya. Hasil yang diperoleh dalam penelitian ini, juga menguatkan beberapa penelitian sebelumnya. Penelitian yang dilakukan oleh Nelly Hagashita pada tahun 2016 dengan judul "Peningkatan Keterampilan Menulis Teks Laporan Hasil Observasi melalui Model Jurisprudensial Berbasis Wisata Lapangan pada Siswa Kelas X IPA 2 SMA Negeri 3 Singaraja". Respons siswa terhadap penerapan model pembelajaran jurisprudensial berbasis wisata lapangan dikatakan positif. Hal ini disebabkan oleh adanya situasi yang memungkinkan terjadinya kegiatan belajar optimal, model pembelajaran tidak monoton serta pemilihan materi yang otentik.

\section{SIMPULAN DAN SARAN}

Ada beberapa hal yang menjadi simpulan dalam penelitian ini. Pertama, langkah-langkah kegiatan pembelajaran melalui metode karyawisata pada pembelajaran menulis teks negosiasi pada siswa kelas X IPA 1 MAN 1 Buleleng adalah sebagai berikut.(1)Tahap awal, pada langkah ini guru memberikan apersepsi dan motivasi terhadap siswa karena sangat berpengaruh terhadap keberhasilan siswa dalam mencapai tujuan pembelajaran. Guru menggunakan kesempatan ini untuk membentuk kelompok belajar. (2)
Penekanan materi; pada tahapan ini, guru memberikan penekanan terhadap materimateri yang perlu dikuasai oleh siswa. Kemudian siswa mendapat arahan dari guru sebelum melaksanakan karyawisata pada objek yang telah ditentukan. (3)Pelaksanaan karyawisata ke pasar; Setelah siswa mendapatkan arahan dari guru, secara bersama-sama siswa melaksanakan karyawisata. (4)Menjelaskan kriteria penilaian; sebelum siswa mulai menulis, guru akan terlebih dahulu menjelaskan kriterian penilaian kepada siswa. Hal ini bertujuan agar tulisan teks negosiasi siswa bisa sesuai atau memenuhi kriteria yang sudah ditetepkan oleh guru. (5) Kegiatan menulis; Pada tahap ini siswa akan membuat sebuah teks negosiasi berdasarkan apa yang sudah ia alami sebelumnya.(6) Penutup; siswa maju membacakan hasil pekerjaannya di depan kelas. Ketika perwakilan kelompok mempresentasikan laporannya, siswa lain menanggapi hasil laporan yang tengah dipresentasikan, sehingga akan terjadi sesi diskusi.

Kedua, Metode karyawisata dapat meningkatkan kemampuan menulis teks negosiasi siswa kelas $X$ IPA 1 MAN 1 Buleleng. Hal ini dapat dilihat dari peningkatan skor rata-rata yang diperoleh siswa dari prasiklus 65,00 (cukup), tindakan siklus I 75,91 (baik), dan tindakan siklus II 83,81 (baik). Selain itu peningkatan kemampuan menulis siswa juga dapat dilihat dari jumlah siswa yang memperoleh nilai sesuai KKM. Pada siklus I, siswa memperoleh nilai sesuai KKM sebesar $68,75 \%$, sedangkan pada siklus siswa memperoleh nilai sesuai KKM sebesar $84,37 \%$. Dari kedua siklus terjadi peningkatan sebesar 15,62\%. Pembelajaran menulis teks negosiasi menggunakan metode karyawisata dikatakan berhasil karena 84,37\% dari jumlah siswa di kelas memperoleh nilai 76 
ke atas (sesuai $\mathrm{KKM}$ ), sehingga tindakan dihentikan.

Ketiga, Respons siswa dalam pembelajaran menulis teks negosiasi menggunakan metode karyawisata adalah positif. Pada siklus I respon siswa secara klasikal dengan skor rata-rata sebesar 42,59 (positif). Pada siklus II atau siklus teraksir, respon siswa secara klasikal dengan skor rata-rata sebesar 43,72 (positif)

Berdasarkan temuan-temuan dalam penelitian ini, peneliti menyampaikan beberapa saran, yaitu (1) siswa disarankan agar lebih memerhatikan aspek teknis dalam menulis. guru dapat menerapkan pendekatan reader respons dalam pembelajaran, (2) guru disarankan agar menerapkan metode karyawisata dalam pembelajaran menulis teks negosiasi. (3) Bagi pihak sekolah, hasil penelitian ini dapat digunakan sebagai pengembangan proses pengajaran Bahasa Indonesia. (4) Bagi peneliti lain, penelitian ini dapat dijadikan sebagai acuan, pedoman, serta bahan perbandingan dalam melakukan penelitian.

\section{DAFTAR PUSTAKA}

Dewi, Putu Novita Susiyanti. 2015. Implementasi Pembelajaran Menulis Teks Negosiasi Berdasarkan Kurikulum 2013 di Kelas XB Akuntansi SMK Negeri 1 Singaraja. Skripsi. Program Studi Pendidikan Bahasa dan Sastra Indonesia, Fakultas Bahasa dan Seni, Universitas Pendidikan Ganesha.

Hagashita, Nelly. 2015. Peningkatan Keterampilan Menulis Teks Laporan Hasil Observasi Melalui Model Jurisprudensial Berbasis Wisata Lapangan Pada Siswa Kelas X Ipa 2 SMA Negeri 3 Singaraja. Skripsi. Jurusan Pendidikan Bahasa dan Sastra Indonesia, Fakultas Bahasa dan Seni, Universitas Pendididkan Ganesha.

Ismawati, Esti. 2012. Perencanaan Pengajaran Bahasa. Yogyakarta: Penerbit Ombak

Kemendikbud. 2013. Buku Guru: Bahasa Indonesia Ekspresi Diri dan Akademik untuk Kelas X. Jakarta: Kementrian Pendidikan dan Kebudayaan.

Nurmaliah, dkk. 2014. "Penggunaan Metode Karyawisata Untuk Meningkatkan Pemahaman Konsep dan Keterampilan Proses Sains Pada Materi Keanekaragaman Hayati". Jurnal Biotik. Edisi April 2014 (halm.24)

Sudjana, Nana. 2002. Metode Statistika. Bandung: Tarsito.

Taufani, Ade Yuanita. 2014. Penerapan Metode Pembelajaran Bermain Peran (Role Playing) untuk Meningkatkan Hasil Belajar Menulis Teks Negosiasi pada Siswa Kelas X SMA Negeri 4 Jember. Skripsi. Jurusan Pendidikan Bahasa dan Seni, Fakultas Keguruan dan Ilmu Pendidikan, Universitas Jember 
Volume 8 Nomor 2, Agustus 2018

P-ISSN : 2614-4743 (cetak) dan e-ISSN : 2614-2007 (online)

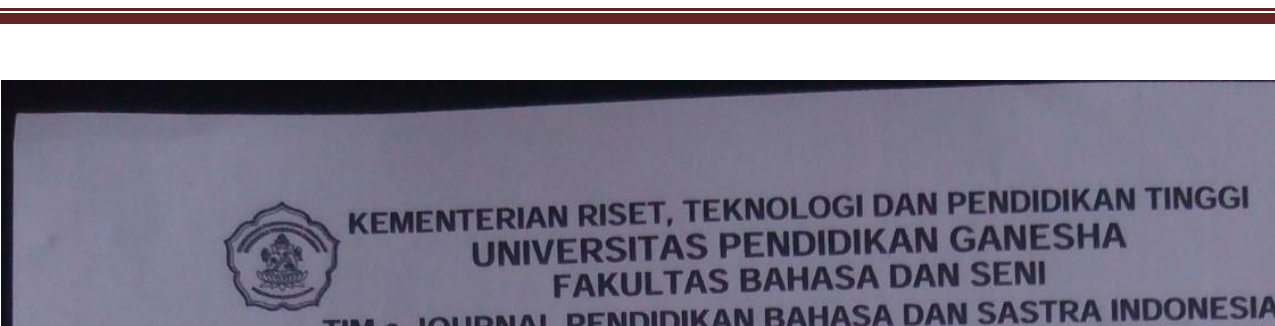

TIM E-JOURNAL PENDIDIKAN BAHASA DAN SASTRA INDONESIA

FORM PERSETUJUAN PEMBIMBING

No : 60/EJPS/ACC/VII/2018

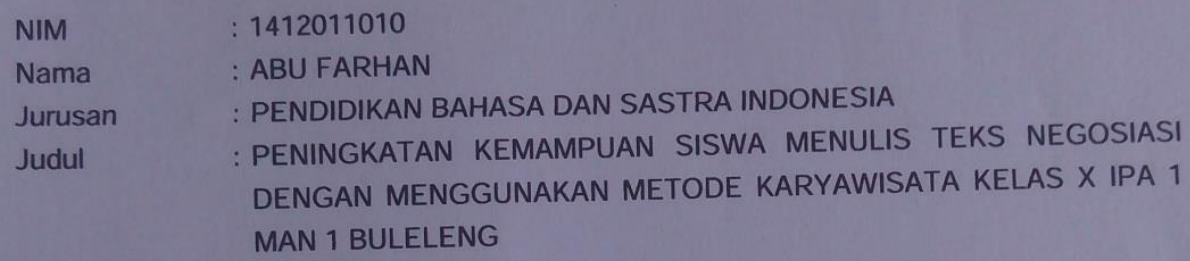

Dengan ini menyatakan bahwa artikel dengan judul di atas sudah diperiksa dan disetujui oleh :

Pembimbing I

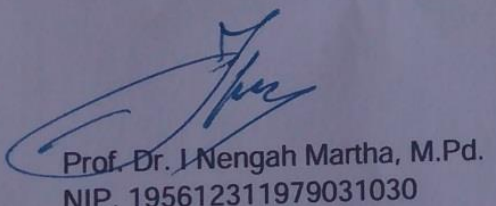

Pembimbing ॥

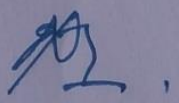

Prof. Dr.Ida Bagus Putrayasa,M.Pd NIP. 196002101986021001 